\title{
Arbitrage Pricing Theory Model Application on Tobacco and Cigarette Industry in Indonesia
}

\author{
Sakina Ichsani ${ }^{a}$, Neneng Susanti ${ }^{a}$, Agatha Rinta Suhardi ${ }^{a}$ \\ ${ }^{a}$ Widyatama University Bandung, Indonesia \\ sakina.ichsani@widyatama.ac.id
}

\begin{abstract}
Purpose of this study was to applicant the Arbitrage Pricing Theory model in the tobacco and cigarette industry listed on the IDX. The APT model in this study uses macroeconomic variables consisting of exports, inflation, exchange rates, GDP and economic growth. Object of this research is companies listed on the Indonesia Stock Exchange in the period 2012-2017 using monthly periods, which is Gudang Garam Tbk., Handjaya Mandala Sampoerna Tbk., and Bentoel International Investama Tbk. This study uses quantitative methods and analysis will be used with regression analysis methods and data processed using Eviews 10. Results of the study show that there are simultaneous effects between the variables of exports (XI), inflation (X2), exchange rates (X3), GDP (X4), and economic growth (X5) on stock returns $(Y)$. There is a significant positive effect between economic growth on stock returns, while there is a significant negative effect between inflation on stock returns and GDP on stock returns. While exports do not affect the stock returns of the tobacco and cigarette industry as well as the exchange rate does not affect stock returns. Suggestions for investors are if investors are going to invest in the tobacco and cigarette industry, then investors should pay attention to the macroeconomic conditions that affect stocks, while for companies can minimize the risks that might occur through agreements between the destination countries for cigarette sales.
\end{abstract}

Article Info

- Received : March 15, 2019

- Revised : May 8, 2019

- Published : June 18, 2019

- No. Pages : $179-187$

- DOI : 10.33019/ijbe.v3i2.160

- JEL : B22, E31, O4, R53

- Keywords : apt model, stock returns

\section{Introduction}

Arbitrage Pricing Theory (APT) is a measurement model of multi-factor asset pricing based on the idea that stock returns can be estimated using macroeconomic variables that are part of systematic risk. Stock return is the level of profit that can be obtained by investors for an investment that has been made. Returns obtained by investors always fluctuate from period to period, so that good information is needed about the company's performance reflected through financial reports and information on the overall economic condition which is often referred to as the macroeconomy. The tobacco processing industry or what is often referred to as the tobacco and cigarette industry contributes to the national economy which includes the absorption of the number of workers, inputs to state revenues and becoming a commodity for farmers. The Ministry of Industry notes that state revenues from this industry increase every 
year, this state income comes from excise and tax. In 2016 the contribution of industrial excise payments reached Rp138.69 trillion or $96.65 \%$ of the total national excise revenue. While the number of workers in the manufacturing and distribution sector of tobacco products reaches 2.28 million people and the tobacco and clove plantation sectors are 1.7 million people. The cigarette industry accounts for $1.66 \%$ of Indonesia's total Gross Domestic Product and contributes to the country's foreign exchange through exports of USD700 million. However, the market share of this industry began to experience a shift along with the increasing public attention to health, so users choose to leave cigarettes or choose cigarettes containing tar and/or low nicotine.

Slowing growth in the non-oil and gas industry in 2018 was caused by the decline in the performance of several industry groups. The biggest negative growth occurred in the chemical, pharmaceutical and traditional medicine industries. The second decline in growth occurred in the paper and paper products, printing and recording media reproduction, then the tobacco processing industry. The decline in growth in the Tobacco Processing industry has occurred since the fourth quarter of 2017. This decline was caused by a decrease in production caused by the number of cigarette companies that stopped operating because they were unable to compete due to increases in cigarette excise and difficulties in obtaining raw materials. In addition, there are currently more and more imported cigarettes and limited amounts of cigarette consumption in the country. In addition, restrictions on tobacco quota also have an impact on decreasing growth. In 2018, the export value of the cigarette processing industry fell by $5.87 \%$ and export volume fell by $7.93 \%$. This decline in exports occurred in exports of cigarette cigarettes at $5.18 \%$ and processed tobacco at $17.38 \%$. The decline in the growth of the tobacco processing industry from the export side is one of them due to the regulation of plain packaging for all tobacco products by the Australian government. This regulation can cause a decline in product competitiveness because it will force the local cigarette industry to adjust prices. If this plain packaging rule is implemented by other countries, it will cause a decline in growing growth because Indonesia is the second largest tobacco producer in the world.

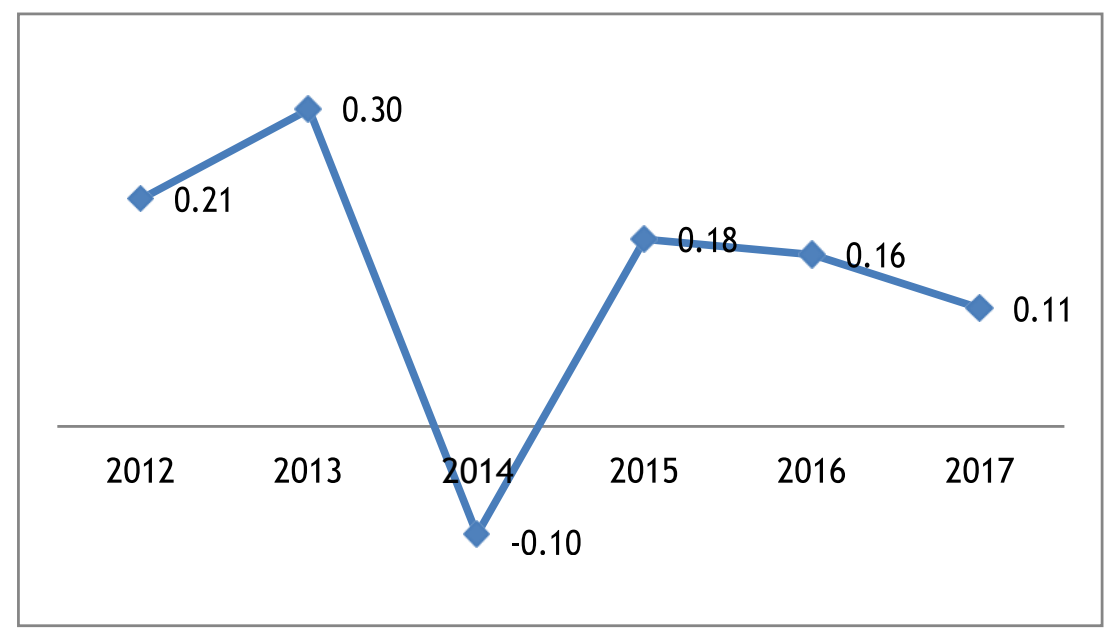

Figure 1: Tobacco and Cigarette Stock Return Growth

In Figure 1 above, we can see the condition of tobacco and cigarette industry stock returns from 2012 until 2017. In 2012-2013 tobacco and cigarette industry stock returns increased by 0.09 points, which is from 0.21 increased to 0.30 . But in 2013-2014 tobacco and cigarette industry stock returns decreased significantly by 0.40 points to reach a negative 0.10 . In 2014-2015 the tobacco and cigarette industry's stock returns returned a significant increase of 
0.28 units to positive 0.18 , but in 2015-2017, cigarette industry stock returns always declined. If viewed in a trend from 2012 to 2017, the cigarette industry's stock returns always decline. The return of cigarette industry stocks that are unstable with sharp fluctuations and a downward trend each year will make investors worried about the value of the shares they invest. Investors can worry about whether the return of shares they get is in accordance with what investors expect or not because the value is very volatile with the downward trend. Based on the background described above, the authors are interested in conducting research with the title "Arbitrage Pricing Theory Applications in Tobacco and Cigarette Industries in Indonesia."

\section{Literature Reviews}

Formulated in 1976 by Stephen Ross states that in the Arbitration Pricing Theory (APT) model, securities returns are not only influenced by the market portfolio because of the assumption that the expectations of a security can be influenced by several other sources of risk (Chandra 2014:18) According to Arbitration Pricing Theory (APT), if there are two investment opportunities that have identical characteristics, it cannot be sold at different prices. It means that the level of profit is influenced by various factors in the economy and industry. The arbitration process will take place when two assets have the same characteristics but expect different returns so that it is possible to buy assets that are cheaper and sell assets that are more expensive. APT will relate to exports, inflation, the exchange rate and the Gross Domestic Product (GDP) in economic growth.

Export is trade by selling goods from inside the country with various applicable regulations. According to Sukirno (2012), the benefits of export activities are expanding the market for Indonesian products, increasing the country's foreign exchange, and expanding employment. Meanwhile, Inflation is a tendency the increase in goods prices that are general in nature and occur continuously (Murni, 2016). If inflation is low, it has a positive influence so that it can push the economy towards a better direction but if inflation is too high it will cause overheated economic chaos. Moreover, the exchange rate is the price of a currency relative to another country's currency (Ekananda 2014). Exchange rates make it possible to translate prices from various countries into the same value. According to Mankiw (2012), GDP is the market value of all goods and services produced in a country in a period. GDP measures the total income of all people in the economy and the total expenditure of the state to buy goods and services produced from the economy at the same time. This is because the GDP of an economy as a whole, income equals expenditure.

Economic growth is a condition where income increases due to an increase in the production of goods and services. The increase in income is not related to the level of population growth, and we can see from increased output, technological developments, and various innovations in the social field. Economic growth can also be interpreted as a process of changing the country's economy in a certain period of time to lead to better economic conditions. Economic growth is identical to the increase in production capacity realized through an increase in national income. A country that experiences economic growth is indicated by the better life of its people. Return is one of the factors that motivate investors to invest and also the results of the courage to bear the risk of the investment (Tendelilin 2010: 47). Return is one of the important factors that investors make in choosing shares to buy. The concept of risk is inseparable from return because investors expect a rate of return that is in accordance with what they invest. Components that form the basis of the return are yields and capital gains. Yield is a return component obtained from investment returns in the form of dividends, 
while capital gains are the difference between the selling price and the purchase price of the stock.

\section{Research Hypothesis}

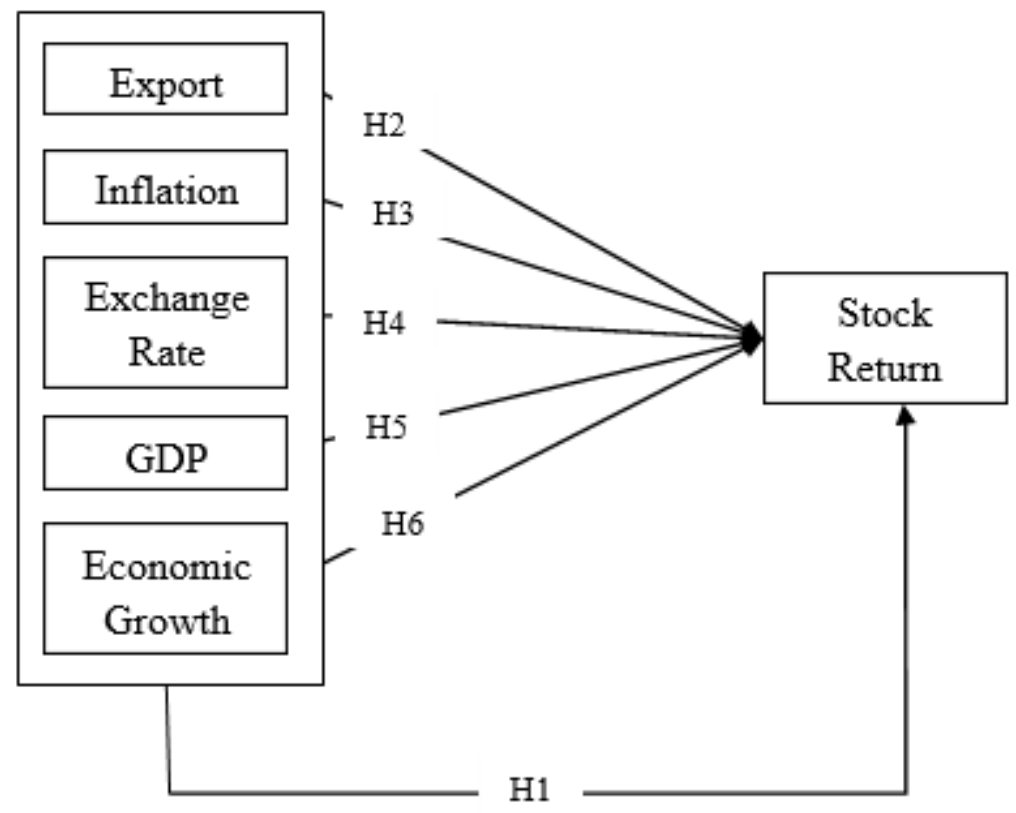

Figure 2. Research Hypothesis

H1: Exports, Inflation, Exchange Rate, GDP and Economic Growth Effects Stock Return on Tobacco and Cigarette Industry Listed on Indonesia Stock Exchange Period 2012-2017.

H2: Exports Effects Stock Return on Tobacco and Cigarette Industry Listed on Indonesia Stock Exchange Period 2012-2017.

H3: Inflation Effects Stock Return on Tobacco and Cigarette Industry Listed on Indonesia Stock Exchange Period 2012-2017.

H4: Exchange Rate Effects Stock Return on Tobacco and Cigarette Industry Listed on Indonesia Stock Exchange Period 2012-2017.

H5: GDP Effects Stock Return on Tobacco and Cigarette Industry Listed on Indonesia Stock Exchange Period 2012-2017.

H6: Economic Growth Effects Stock Return on Tobacco and Cigarette Industry Listed on Indonesia Stock Exchange Period 2012-2017.

\section{Research Methods}

In this study, the research object was a company listed in the manufacturing industryconsumer goods sector-tobacco and cigarette subsector in the Indonesia Stock Exchange for the period 2012-2017. The sampling method in this study used purposive sampling. According to Sugiyono (2017: 124), purposive sampling is a sampling technique with certain considerations. The reason for choosing this sampling technique is because not all companies meet the criteria the authors specify. Based on the criteria that the author has set, the sample of this study is 3 (three) companies, which is Gudang Garam Tbk., Handjaya Mandala Sampoerna Tbk., Bentoel International Investama Tbk. The period of this research was 6 years using monthly periods. The research method in this study uses quantitative methods and analysis will be used with regression analysis methods and data processed using Eviews 10. Based on what has been described above, the subject of this research is exports (X1), inflation (X2), exchange rates (X3), GDP (X4), economic growth (X5) and stock returns (Y). 


\section{Results}

\section{Results}

Table 1. Data Panel Regression Analysis (Fixed Effect Model)

\begin{tabular}{|c|c|c|c|c|}
\hline $\begin{array}{l}\text { Dependent Variable: RETURN_S } \\
\text { Method: Panel Least Squares } \\
\text { Date: 03/01/19 Time: } 13: 21 \\
\text { Sample: } 20122017 \\
\text { Periods included: } 6 \\
\text { Cross-sactions includad: } 3 \\
\text { Total panel (balanced) observation }\end{array}$ & & & & \\
\hline Variable & Confficient & Std. Error & t-Statistic & Prob. \\
\hline c & -3.645600 & 73.13799 & -0.049846 & 0.0012 \\
\hline EKSPOR & -3.106960 & 2.185802 & -1.421428 & 0.1856 \\
\hline MFLASI & -0.270074 & 0.307678 & -0.877782 & 0.0007 \\
\hline KLRS & 23.85114 & 114.7631 & 0.207829 & 0.8395 \\
\hline PDB & -0.891292 & 2.052121 & -0.434327 & 0.0433 \\
\hline PERTUMIRUHAN_EKONOMI & 16.54707 & 11.56221 & 1.431134 & 0.0129 \\
\hline & Effects Sp & cification & & \\
\hline Cross-section fixed (dummy vari & & & & \\
\hline $\begin{array}{l}\text { R-squared } \\
\text { Adjusted R-squared }\end{array}$ & $\begin{array}{l}0.674364 \\
0.446418\end{array}$ & $\begin{array}{l}\text { Mean depunder } \\
\text { S.D. depundm }\end{array}$ & & $\begin{array}{l}1.142707 \\
0.272554\end{array}$ \\
\hline S.E. of regression & 0.202788 & Alsaike info cri & & -0.052207 \\
\hline
\end{tabular}

From Table 1, it can be interpreted that the constant value is -3.6456 , this states that if exports (X1), inflation (X2), exchange rates (X3), GDP (X4), and economic growth (X5) equals zero and there is no change (considered constant), then the stock return (Y) in the tobacco and cigarette industry is -3.6456 . The regression coefficient of exports value (X1) is negative at 3.106960, which means that every increase in one point of export (X1) will reduce stock returns $(\mathrm{Y})$ in the tobacco and cigarette industry by 3.106960 points. The inflation coefficient regression value $(\mathrm{X} 2)$ is negative at 0.270074 , which means that every increase in one point of inflation (X2) will reduce stock return (Y) in the tobacco and cigarette industry by 0.270074 points. The regression

coefficient value of the exchange rate (X3) is positive at 23.85114, which means that every increase in one point of exchange rate (X3) will increase the stock return (Y) in the tobacco and cigarette industry by 23.85114 points. The regression coefficient value of GDP (X4) has a negative sign of 0.891292 which means that every increase in one point of GDP (X4) will reduce stock returns $(\mathrm{Y})$ in the tobacco and cigarette industry by 0.891292 points. The regression coefficient value of economic growth (X5) is positive at 16.54707 which mean that every increase in one point of economic growth value (X5) will increase stock returns (Y) in the tobacco and cigarette industry by 16.54707 points.

Based on the simultaneous test results it is known that F-statistics is 2.9584, while the Ftable value with a significance level of $5 \%$ is 2.48 , from these results it is known that the F-statistic value is greater than the Ftable value, the meaning of this results is there is a significant effect between the export variable (X1), inflation (X2), exchange rate (X3), GDP (X4), and economic growth (X5) simultaneously on stock returns (Y) in the tobacco and cigarette industry. The variable Export (X1), inflation (X2), exchange rate (X3), GDP (X4), and 
economic growth (X5) explain the variation of stock returns in the tobacco and cigarette industry by 67.44 percent, the rest is determined by other variables outside the research model. This result implies that the variables in this study consisting of exports, inflation, exchange rates, GDP and economic growth are able to explain variations on stock returns in the tobacco and cigarette industry very well.

Partial testing conducted in this study found that the variable economic growth (X5) has a significant effect on stock returns (Y) in the tobacco and cigarette industry with the direction of effect is positive. It is known that the significance value of the variable economic growth (X5) is smaller than Significance level that previously set at 0.05, with the direction of a positive relationship known from the positive t-statistical value. The inflation variable (X2) and GDP (X4) in this study also have a significant effect on stock returns (Y) in the tobacco and cigarette industry, but only the direction of the effect is negative. It is known that the significance value of the inflation variable (X2) and GDP (X4) is smaller than Significance level that previously set at 0.05 ; the negative relationship direction is known from the negative t-statistical value. While the export (X1) and exchange rate (X3) does not have a significant effect on stock returns (Y) in the tobacco and cigarette industry, this is known from the significance value of the export variable (X1) and exchange rate (X3) is greater than the Significance level that previously set at 0.05 .

\section{Discussion}

From this study it was found that the variable of export (X1), inflation (X2), exchange rate (X3), GDP (X4) and economic growth (X5) simultaneously had an influence on stock returns $(\mathrm{Y})$ in the tobacco and cigarette industry, because the t-table value with a significance level of 0.05 is less than the t-statistic value. The magnitude effect of exports (X1), inflation (X2), exchange rates (X3), GDP (X4) and economic growth (X5) on stock returns (Y) in the tobacco and cigarette industry is $67.44 \%$ while $32.56 \%$ is influenced by other factors outside the variable examined. This means that the variables in this study can already be used because the ability of dependent variable to explain stock returns in the tobacco and cigarette industry is very good. Therefore, the management of the company who's directly related to decision-making decisions in the company must control or evaluate the variables in this study so the risk of decreasing stock returns in the long term can be minimized. However, the company cannot control these variables directly, because these variables are external or macroeconomic variables that are influenced outside of company policy. But this can be dealt with continuous evaluation of cooperation policies, the policies carried out must also consider other variables not examined in this study. The results of this study are consistent with the research conducted by Ginting (2013); Purnomo and Widyawati (2013); Afiyati and Topowijono (2018).

The results of the study show that there is no influence between the export variables on stock returns in the tobacco and cigarette industry, where the significant value generated is 0.1856 greater than significance level 0.05 . This indicates that the plain packaging policy applied by the Australian government for imported cigarettes did not affect the Indonesia tobacco and cigarette industry stock returns. This plain packaging policy is feared can be applied to be the policy of other cigarette importing countries, which are feared to affect the income of cigarette companies in Indonesia, which in turn will affect the cigarette industry's shares. But apparently, this does not affect the stock returns of the tobacco and cigarette industry in Indonesia. The results of this study are consistent with the research conducted by Paloma (2012) 
Moreover, this study shows that there is a negative significant influence between inflation on stock returns in the tobacco and cigarette industry, where the value of significance produced is 0.0007 smaller than significance level 0.05. This result has an indication that the higher the inflation occurs it can reduce stock returns in the tobacco and cigarette industry. If inflation occurs, prices will increase, while people's real income will decrease and will have an impact on purchasing power which also decreases. Cigarettes are not a basic necessity of everyday society. Cigarette consumption can be reduced if people's purchasing power decreases due to inflation. If cigarette consumption decreases, it will reduce the cigarette industry share price. This is what causes the decline in cigarette industry stock returns if inflation rises. In addition, the occurrence of inflation will result in a decrease in the value of company assets, which causes the value of goods owned by the company as a whole will decrease. But if there is deflation, the opposite condition will occur, namely, stock returns will increase. The results of this study support previous studies conducted by Hidayat et al. (2017).

There is no influence between the exchange rate on stock returns in the tobacco and cigarette industry, where the value of the significance level is 0.8395 greater than significance level 0.05. According to the results of the above research that exports do not affect stock returns in the tobacco and cigarette industry, the exchange rate does not affect the tobacco and cigarette industry stock returns. If the sale of cigarettes abroad is not affected by the policies implemented by the local government, so that it does not affect the export of cigarettes from Indonesia, the rupiah exchange rate against foreign currencies will not be affected. Moreover, most of the raw materials for making cigarettes use domestic raw materials whose transactions use rupiah. The results of this study support previous studies conducted by Pujawati et al. (2015) and Suriyani \& Sudiartha (2018).

Negative significant influence between GDP on stock returns in the tobacco and cigarette industry, where the significance value produced is 0.0433 smaller than significance level 0.05. This has an understanding that if GDP increases, it will cause a decrease in stock returns in the tobacco and cigarette industry. The results of this study are in line with Sangkyun and Hooker on (Kewal: 2012). The results of the study show that there is a positive significant influence between the economic growth on stock returns in the tobacco and cigarette industry, where the significance value produced is 0.0129 smaller than significance level 0.05 . This has an understanding of economic growth has increased; it will result in an increase in stock returns in the tobacco and cigarette industry. Increasing economic growth will increase people's purchasing power and consumption because people have more funds as a result of increasing economic growth. These funds can be used by investors to invest in stocks, one of which is invested in the cigarette industry. The results of this study are in line with the research of Bambang Sukono Indarto (2012) and Kristiyawati and Kesi Wijajanti (2012)

\section{Conclusion and Suggestion}

From results and discussion that have been conducted, this study found that simultaneously the dependent which is exports (X1), inflation (X2), exchange rate (X3), GDP (X4), and economic growth (X5) had a significant effect on stock returns in the tobacco and cigarette industry. While partially the inflation (X2) and GDP (X4) has a significant effect on stock returns in the tobacco and cigarette industry in a negative direction. The economic growth (X5) has a significant effect on stock returns in the tobacco and cigarette industry in a positive direction. While the export (X1) and exchange rate (X3) does not significantly influence stock returns in the tobacco and cigarette industry. Based on the conclusions of the study, the suggestion that the authors give is that the further researcher can then use the 
company in other industries as a comparison material or can add research variables that affect stock returns. For investors, if they are going to invest in stocks in the tobacco and cigarette industry, investors should pay attention to the macroeconomic conditions that affect stocks. For companies, they can minimize the risks that might occur through agreements between the destination countries for cigarette sales.

\section{References}

1) Afiyati, H. T., \& Topowijono. (2018). Pengaruh Inflasi, BI Rate, Dan Nilai Tukar Terhadap Return Saham (Studi Pada Perusahaan Subsektor Food \& Beverages Yang Terdaftar Di Bursa Efek Indonesia Periode 2013-2016). Jurnal Administrasi Bisnis (JAB) Vol. 61 No. 2 Agustus 2018.

2) Amir, M. S. (2008). Handbook of Export Import Business. Edisi Pertama. Victory Jaya Abadi: Jakarta.

3) Akpo, E. S., Hassan, S., \& Esuike, B. U. (2015). Reconciling The Arbitrage Pricing Theory (APT) and The Capital Asset Pricing Model (CAPM) Institutional and Theoretical Framework. International Journal of Development and Economic Sustainability Vol. 3 No. 6.

4) Badan Pusat Statistik. (2018). Pertumbuhan Produksi industri. https://www.bps.go.id/pressrelease/ 2018/02/01/1479/pertumbuhan-produksi-industri-manufaktur- besar-dan-sedang-triwulan-ivtahun-2017-naik-sebesar-5-15-persen-dan-pertumbuhan-produksi- industri-manufaktur-mikrodan-kecil-triwulan-iv-2017-naik-sebesar-4-59-persen.html

5) Chandra, A. (2014). Prediksi Return Saham: Perbandingan berdasarkan CAPM dan APT Pada Perusahaan Lq-45 di Bursa Efek Indonesia. http://respository.wima.ac.id/1147.

6) Ekananda, M. (2014). Ekonomi Internasional. Jakarta: Erlangga

7) Ginting, M. R. M. (2016). Pengaruh Tingkat Suku Bunga, Nilai Tukar dan Inflasi Terhadap Harga Saham. Jurnal Administrasi Bisnis: Vol.35 No. 2

8) Hidayat, L. R., Setyadi, D., \& Azis, M. (2017). Pengaruh Inflasi Dan Suku Bunga Dan Nilai Tukar Rupiah Serta Jumlah Uang Beredar Terhadap Return Saham. FORUM EKONOMI Volume 19 (2), 2017.

9) Indarto, B. S. (2012). Analisis Faktor-Faktor yang Mempengaruhi IHSG di Bursa Efek Indonesia Periode Tahun 2007-2011. Jurnal Ilmiah USM.

10) Kemenperin RI. (2018). Laporan Analisis Perkembangan Industri. http://www.kemenperin.go.id /download/19418/Laporan-Analisis-Perkembangan-Industri-Edisi- II-(Triwulan-I)-2018.

11) Kewal, S. S. (2012). Pengaruh Inflasi, Suku Bunga, Kurs, PDB terhadap IHSG. Jurnal Economica Vol 8 No 1 April 2012.

12) Kristiyawati \& Kesi, W. (2012). Analisis Pengaruh Tingkat Suku SBI, Kurs, Jumlah Uang Beredar dan Indeks Dow Jones terhadap IHSG di Bursa Efek Indonesia. Jurnal Ilmiah USM.

13) Lisa, P. W. (2002). Analisis Pengaruh Tingkat Inflasi, Suku Bunga, Kurs and Laju Pertumbuhan Ekonomi terhadap Return Saham di Bursa Efek Jakarta. Tesis. Program Studi Magister Manajemen Universitas Diponegoro.

14) Mankiw, N. G. (2012). Principles of Macroeconomics, Sixth Edition. Canada: Cengage Learning

15) Murni, A. (2016). Ekonomika Makro. Edisi Revisi. Bandung: Refika Aditama

16) Mulyadi. (2014). Sistem Akuntansi (Ed. Ke-3). Jakarta: Salemba Empat

17) Nopirin. (2010). Ekonomi Moneter. Buku I Edisi ke-4 Cetakan Kesepuluh. Yogyakarta, BPFE.

18) Purnamawati, A. (2013). Dasar-Dasar Ekspor Impor. UPP STIM YKPN: Yogyakarta.

19) Purnomo, T. H., \& Nurul, W. (2013). Pengaruh Nilai Tukar, Suku Bunga, Dan Inflasi Terhadap Return Saham Pada Perusahaan Properti. Jurnal Ilmu \& Riset Manajemen: Vol. 2 No. 10

20) Pujawati, P. E., Wiksuana., I. G. B., \& Artini, L. G. S. (2015). Pengaruh Nilai Tukar Rupiah Terhadap Return Saham Dengan Profitabilitas Sebagai Variabel Intervening. E-Jurnal Ekonomi dan Bisnis Universitas Udayana 4.04 (2015): 220-242.

21) Sutedi, A. (2014). Hukum Ekspor Impor. Raih Asa Sukses. Penebar Swadaya Grup, Jakarta.

22) Sukirno, S. (2012). Makroekonomi Teori Pengantar. Edisi Ketiga. Jakarta: Rajawali Pers.

23) Susilo, A. (2013). Panduan Pintar Ekspor Impor. TransMedia, Jakarta. 
IJBE (Integrated Journal of Business and Economics)

e-ISSN: 2549-3280/p-ISSN: 2549-5933

24) Sugiyono. (2017). Metode Penelitian Kuantitatif, Kualitatif, dan R\&D. Bandung: Alfabeta

25) Suriyani, N. K \& Sudiartha, G. M. (2018). Pengaruh Tingkat Suku Bunga, Inflasi Dan Nilai Tukar Terhadap Return Saham Di Bursa Efek Indonesia. E-Jurnal Manajemen Unud, Vol. 7, No. 6, 2018: 3172-3200. 